\title{
Perbandingan Kualitas Hidup Pasien yang Menjalani Hemodialisis dengan Terapi Epoetin Alfa dan Epoetin Beta di RS PKU Muhammadiyah Yogyakarta
}

\section{Comparison of Quality of Life of Patients Those Undergoing Hemodialysis with Epoetin Alfa and Epoetin Beta Therapy in PKU Muhammadiyah Yogyakarta Hospital}

\author{
Lusia Murtisiwi ${ }^{1}$, Tri Murti Andayani ${ }^{2}$ dan Endang Yuniarti ${ }^{3}$ \\ 1'lusiasiwi@yahoo.co.id, ${ }^{2}$ trimurtia@yahoo.com, ${ }^{3}$ yoen_aji@yahoo.co.id \\ ${ }^{1}$ Akademi Farmasi Nasional Surakarta \\ ${ }^{2}$ Fakultas Farmasi, Universitas Gadjah Mada \\ ${ }^{3}$ Instalasi Farmasi, RS PKU Muhammadiyah
}

\begin{abstract}
Abstrak
Penderita penyakit ginjal kronis (PGK) yang menjalani hemodialisis umumnya mengalami anemia. Anemia pada PGK dapat diterapi dengan pemberian epoetin. Kualitas hidup merupakan aspek yang penting dievaluasi sebagai outcome dari intervensi pada pasien hemodialisis. Penelitian ini bertujuan untuk mengetahui perbedaan kualitas hidup pasien yang menjalani hemodialisis dengan terapi epoetin alfa dan epoetin beta di RS PKU Muhammadiyah Yogyakarta.

Penelitian cross sectional terhadap pasien hemodialisis rutin di RS PKU Muhammadiyah Yogyakarta ini dilakukan pada bulan November 2014Januari 2015. Penilaian kualitas hidup pasien menggunakan kuesioner KDQOL-SF versi 1.3. Subyek penelitian ini terdiri dari dua kelompok, kelompok pertama merupakan pasien yang menggunakan epoetin alfa untuk penanganan anemia, sedangkan kelompok kedua merupakan pasien yang menggunakan terapi epoetin beta untuk penanganan anemia. Data dianalisis menggunakan Levene test, Chi-Square Goodness of Fit, Independent t-test, uji Mann-Whitney dan uji ANCOVA.

Hasil penelitian menunjukkan bahwa secara umum kualitas hidup keseluruhan pasien yang menjalani hemodialisis dengan terapi epoetin alfa dan epoetin beta di RS PKU Muhammadiyah Yogyakarta menunjukkan hasil yang berbeda tidak bermakna $(p>0,05)$ yaitu sebesar $60,25 \pm 12,97$, pada kelompok epoetin alfa dan $63,93 \pm 15,53$ pada kelompok epoetin beta.
\end{abstract}

Kata kunci: kualitas hidup, epoetin alfa, epoetin beta, KDQOL-SF, PGK

\section{Abstract}

In patients with chronic kidney disease who undergo hemodialysis are anemic. Anemia in chronic kidney disease (CKD) can be treated by administration of epoetin. Quality of life is an important aspect evaluated as outcomes of intervention in hemodialysis patients. This study aims to determine differences in the quality of life for patients undergoing hemodialysis therapy with epoetin alfa and epoetin beta in PKU Muhammadiyah Yogyakarta Hospital. 
Cross-sectional study on regular hemodialysis patients in PKU Muhammadiyah Yogyakarta Hospital was conducted in November 2014January 2015. Assessment of the quality of life of patients using questionnaires KDQOL-SF version 1.3. The subjects of this study consisted of two groups, the first group of patients using epoetin alfa for treatment anemia, while the second group is patients taking epoetin beta therapy for the treatment of anemia. Data were analyzed using Levene test, Chi-Square Goodness of Fit, Independent t-test, Mann-Whitney test and ANCOVA.

The results showed that in general the overall quality of life for patients undergoing hemodialysis therapy with epoetin alfa and epoetin beta in RS PKU Muhammadiyah Yogyakarta showed different results was not significant $(p>0.05)$ in the amount of $60.25 \pm 12.97$, group epoetin alfa and $63.93 \pm 15.53$ in the epoetin beta group.

\section{Keywords: quality of life, epoetin alfa, epoetin beta, KDQOL-SF, CKD}

\section{Pendahuluan}

Pasien penyakit ginjal kronis (PGK) umumnya menjalani hemodialisis secara rutin. Terapi ini akan berlangsung terus menerus sepanjang kehidupan pasien kecuali jika pasien menjalani transplantasi ginjal (Smeltzer, 2005). Pola terapi pasien PGK mencakup lamanya menjalani hemodialisis, frekuensi hemodialisis per minggu, durasi setiap hemodialisis, dan terapi eritropoetin.

Pasien penyakit ginjal kronis (PGK) yang menjalani hemodialisis pada umumnya mengalami anemia. Anemia pada pasien PGK terjadi terutama karena kekurangan eritropoetin (Eschbach, 2000; PERNEFRI, 2011). Prevalensi anemia pada pasien PGK menurut WHO adalah $84,5 \%$ dengan prevalensi pada pasien dialisis kronik menjadi $100 \%$ dan $73,1 \%$ pada pasien pradialisis. Di Amerika Serikat, menurut data USRDS 2010 angka kejadian anemia pada PGK stadium 1-4 adalah sebesar 51,8\%, dan kadar $\mathrm{Hb}$ rata-rata pada PGK tahap akhir 9,9 g/dL. Di Indonesia belum ada data epidemiologi anemia pada PGK yang bersifat nasional (PERNEFRI, 2011). Anemia pada pasien penyakit ginjal kronis terbukti dapat mempengaruhi kualitas hidup, meningkatkan morbiditas dan mortalitas (Valderrabano dkk., 2000).

Anemia pada PGK dapat diterapi dengan pemberian recombinant Human Erythropoetin (r-HuEPO). Kualitas hidup merupakan aspek yang penting dievaluasi sebagai outcome dari intervensi pada pasien hemodialisis. Kualitas hidup juga terbukti berhubungan dengan hospitalisasi dan kematian pada pasien gagal ginjal tahap akhir (Loos dkk., 2003). Rumah sakit (RS) PKU Muhammadiyah Yogyakarta merupakan salah satu RS di Yogyakarta yang melayani hemodialisis dengan tingkat kunjungan yang tinggi. Berdasarkan studi pendahuluan yang dilakukan, pada bulan Oktober-November 2014 jumlah pasien yang menjalani hemodialisis rutin di RS tersebut berjumlah 135 pasien per bulan. Terkait dengan pembiayaan hemodialisis, RS PKU Muhammadiyah Yogyakarta saat ini melayani pasien hemodialisis dengan model pembayaran Badan Penyelenggara Jaminan Kesehatan (BPJS). Salah satu terapi yang ditanggung oleh BPJS berdasarkan Keputusan Menteri Kesehatan Republik Indonesia Nomor 328/ Menkes/ SK/ VIII/ 2013 tentang Formularium Nasional (FORNAS) adalah eritropoetin alfa dan eritropoetin beta. Harga salah satu produk sepoetin alfa (Hemapo) $3000 \mathrm{U}$ adalah Rp.173.000,-, sedangkan harga salah satu produk epoetin beta (Recormon) $2000 \mathrm{U}$ adalah Rp.139.500. Terkait dengan tingginya kebutuhan akan terapi epoetin, dan kondisi di pasaran bahwa pernah terjadi kekosongan salah satu produk epoetin, maka perlu dilakukan penelitian untuk mengetahui perbedaan kualitas hidup pasien hemodialisis yang menggunakan terapi epoetin alfa dan epoetin beta. Hasil penelitian ini diharapkan dapat memberikan tambahan informasi bagi pengambil kebijakan atau pemangku kepentingan RS terkait kebijakan terapi epoetin bagi pasien. 
Mengingat pentingnya evaluasi kualitas hidup pada pasien PGK yang menjalani hemodialisis dan aspek keamanan terapi epoetin alfa dan beta tersebut, maka perlu dilakukan penelitian perbandingan kualitas hidup pasien yang menjalani hemodilisis dengan terapi epoetin alfa dan epoetin beta di rumah sakit PKU Muhammadiyah Yogyakarta.

\section{Metode Penelitian}

Penelitian ini merupakan penelitian observasional analitik dengan desain potong lintang (cross sectional) karena data yang menyangkut variabel bebas dan variabel terikat dikumpulkan dalam waktu yang bersamaan. Subyek penelitian ini terdiri dari dua kelompok, kelompok pertama merupakan pasien yang menggunakan epoetin alfa untuk penanganan anemia, sedangkan kelompok kedua merupakan pasien yang menggunakan terapi epoetin beta untuk penanganan anemia. Pengumpulan data dilakukan secara concurrent untuk mendapatkan nilai kualitas hidup pasien melalui pengisian kuesioner. Data lain diperoleh dari Buku Pemantauan Obat bagi Peserta Program Pengobatan Penyakit Kronis pasien dan dari rekam medik pasien. Penelitian dilakukan pada pasien hemodilisis peserta BPJS, dilakukan pada bulan November 2014Januari 2015. Data dianalisis menggunakan Chi-Square, Independent t-test dan uji Mann-Whitney serta ANCOVA. Teknik sampling yang digunakan pada penelitian ini adalah consecutive sampling.

Kriteria inklusi pada penelitian ini meliputi pasien berusia $\geq 18$ tahun, pasien menjalani hemodialisis rutin minimal 3 bulan sebelum penelitian, mendapat terapi epoetin alfa $3000 \mathrm{U}$ atau epoetin beta $2000 \mathrm{U}$ jika mengalami anemia selama minimal 3 bulan sebelum penelitian, dapat membaca dan menulis, kesadaran composmentis, memiliki fungsi kognitif yang baik, serta bersedia ikut serta dalam penelitian dengan menandatangani informed consent.

Kriteria eksklusi pada penelitian ini meliputi pasien yang menjalani transplantasi ginjal, kemoterapi, penderita Human Immuno Deficiency Virus (HIV)/ acquired immunodeficiency syndrome (AIDS) dan penderita penyakit keganasan serta pasien hemodialisis yang menjalani rawat inap di RS PKU Muhammadiyah Yogyakarta.

Variabel pada penelitian ini meliputi variabel bebas antara lain terapi epoetin yang diberikan yaitu epoetin alfa $3000 \mathrm{U}$ dan epoetin beta $2000 \mathrm{U}$. Variabel terikat dalam penelitian ini adalah skor kualitas hidup yang meliputi 24 penilaian kualitas hidup pada kuesioner KDQOL-SF versi 1.3, dan persentase adverse event dari epoetin alfa maupun epoetin beta. Variabel perancu dalam penelitian ini meliputi jenis kelamin, usia, komorbid, lama menjalani hemodialisis, frekuensi hemodialisis dalam satu minggu, durasi setiap hemodialisis, dan lama penggunaan epoetin.

Data karakterisitik pasien diperoleh dari rekam medik (RM) dan Buku Pemantauan Obat bagi Peserta Program Pengobatan Penyakit Kronis pasien. Data kualitas hidup pasien diperoleh melalui pengisian kuesioner KDQOL-SF versi 1.3 melalui wawancara dengan pasien. Penelitian dilakukan di unit Hemodialisis RS PKU Muhammadiyah Yogayakarta pada bulan November 2014-Januari 2015. Data dianalisis menggunakan Chi-Square test, Independent t-test, uji Mann-Whitney, dan uji ANCOVA.

\section{Hasil dan Pembahasan \\ Karakteristik Pasien}

Jumlah subyek penelitian ini sebanyak 96 pasien yang terdiri dari dua kelompok. Kelompok pertama merupakan pasien hemodialisis rutin yang menggunakan epoetin alfa $2000 \mathrm{U}$ $1-2 \mathrm{x}$ per minggu, sedangkan kelompok kedua merupakan pasien hemodialisis rutin yang menggunakan epoetin beta 3000 U 1-2x per minggu. Jumlah subyek pada kelompok pertama sebanyak 64 pasien, sedangkan jumlah subyek pada kelompok kedua sebanyak 32 pasien.

Karakteristik subyek penelitian dianalisis secara statistik terlebih dahulu untuk melihat proporsi pasien. Analisis proporsi pasien yang digunakan adalah 
Chi-Square Test, namun apabila syarat ChiSquare Test tidak terpenuhi maka Likelihood Ratio atau Fisher's Exact Test dapat digunakan sebagai alternatif. Proporsi subyek penelitian dikatakan berbeda bermakna jika nilai $\mathrm{p}<0,05$.
Hasil analisis karakteristik/ homogenitas variabel numerik subyek penelitian dapat dilihat pada tabel I, sedangkan karakteristik/ homogenitas variabel skala kategorik pasien dapat dilihat pada tabel II.

Tabel I. Karakteristik/ homogenitas variabel numerik pasien hemodialisis yang menggunakan epoetin alfa dan epoetin beta di RS PKU Muhammadiyah Yogyakarta

\begin{tabular}{|c|c|c|c|c|c|c|c|}
\hline \multirow{3}{*}{$\begin{array}{c}\text { Karakteristik } \\
\text { Subyek }\end{array}$} & \multicolumn{6}{|c|}{ Kelompok } & \multirow[t]{3}{*}{ p-value } \\
\hline & \multicolumn{3}{|c|}{ Epoetin Alfa $(n=64)$} & \multicolumn{3}{|c|}{ Epoetin Beta $(n=32)$} & \\
\hline & Mean \pm SD & Min & Max & Mean \pm SD & Min & Max & \\
\hline Usia & $52,47 \pm 12,117$ & 23 & 75 & $48,94 \pm 10,038$ & 24 & 70 & 0,260 \\
\hline $\begin{array}{l}\text { Lama menjalani } \\
\text { hemodialisis } \\
\text { (tahun) }\end{array}$ & $3,945 \pm 3,4728$ & 0,2 & 18,7 & $4,422 \pm 2,3158$ & & & 0,114 \\
\hline $\mathrm{Hb}(\mathrm{g} / \mathrm{dL})$ & $9,719 \pm 1,3114$ & 7,3 & 13,4 & $9,341 \pm 1,1946$ & 7,2 & 12,0 & 0,976 \\
\hline $\begin{array}{c}\text { Lama } \\
\text { penggunaan } \\
\text { epoetin (bulan) }\end{array}$ & $27,3961 \pm 22,266$ & 1,0 & 151 & $21,281 \pm 28,4256$ & 3,0 & 151 & 0,624 \\
\hline
\end{tabular}

Keterangan: uji homogenitas dilakukan dengan Levene's test

Tabel II. Karakteristik/ homogenitas variabel skala kategorik pasien hemodialisis yang menggunakan epoetin alfa dan epoetin beta di RS PKU Muhammadiyah Yogyakarta

\begin{tabular}{|c|c|c|c|c|c|c|}
\hline \multirow{3}{*}{\multicolumn{2}{|c|}{ Karakteristik Subyek }} & \multicolumn{4}{|c|}{ Kelompok } & \multirow{4}{*}{$\frac{p \text { value }}{0,005^{*}}$} \\
\hline & & \multicolumn{2}{|c|}{ Epoetin Alfa } & \multicolumn{2}{|c|}{ Epoetin Beta } & \\
\hline & & \multirow{2}{*}{$\frac{\mathrm{n}(=64))}{38}$} & \multirow{2}{*}{$\frac{\%}{(59,4)}$} & \multirow{2}{*}{$\frac{\mathrm{n}(=32)}{17}$} & \multirow{2}{*}{$\frac{\%}{(40,6)}$} & \\
\hline Jenis kelamin & Laki-laki & & & & & \\
\hline & Perempuan & 26 & $(53,1)$ & 15 & $(46,9)$ & 0,086 \\
\hline Kategori usia & $18-59$ th & 44 & $(68,8)$ & 28 & $(31,2)$ & 0,059 \\
\hline & $\geq 60$ th & 20 & $(87,5)$ & 4 & $(12,5)$ & $0,001^{*}$ \\
\hline Frekuensi & & & $(71,9)$ & & $(28,1)$ & \\
\hline \multirow{2}{*}{$\begin{array}{l}\text { hemodialisis per } \\
\text { minggu }\end{array}$} & $2 \mathrm{x}$ & 46 & & 20 & & $0,001^{*}$ \\
\hline & $3 x$ & 18 & $(62,5)$ & 12 & $(37,5)$ & 0,273 \\
\hline \multirow[t]{2}{*}{$\begin{array}{l}\text { Durasi setiap } \\
\text { hemodialisis }\end{array}$} & 3,5 jam & 4 & $(6,3)$ & 1 & $(93,8)$ & 0,180 \\
\hline & $4 \mathrm{jam}$ & 60 & $(3,1)$ & 31 & $(96,9)$ & $0,002^{*}$ \\
\hline \multirow[t]{2}{*}{ Kategori kadar $\mathrm{Hb}$} & $<10,5$ & 49 & $(76,6)$ & 25 & $(23,4)$ & $0,005^{*}$ \\
\hline & $>10,5$ & 15 & $(78,1)$ & 7 & $(21,9)$ & 0,088 \\
\hline \multirow[t]{2}{*}{ Komorbid } & Hipertensi & 54 & $(84,4)$ & 29 & $(15,6)$ & $0,006^{*}$ \\
\hline & $\begin{array}{c}\text { Hipertensi+ } \\
\text { DM }\end{array}$ & 10 & $(90.6)$ & 3 & $(4,7)$ & 0,052 \\
\hline
\end{tabular}

Keterangan: data dianalisis menggunakan Chi-Square Goodness-of-Fit Test.

*berbeda bermakna secara statistik

Jumlah pasien laki-laki yang menjalani hemodialisis pada penelitian ini lebih banyak daripada perempuan. Pasien yang menjalani hemodialisis di RS PKU Muhammadiyah Yogyakarta dengan terapi epoetin alfa terdiri dari 38 pasien laki-laki dan 17 perempuan, sedangkan pasien yang menggunakan epoetin beta terdiri dari 26 pasien laki-laki dan 15 pasien perempuan. Hal ini sejalan dengan beberapa penelitian sebelumnya, pada penelitian Wandilla (2014) di RS Akademik persentase pasien laki-laki sebesar 62,5\%. Pada penelitian Septiwi (2010), persentase pasien laki-laki yang menjalani hemodialisis di RS Margono Soekarjo Purwokerto sebanyak 58,4\%. Safarudin (2012) juga diperoleh gambaran jumlah pasien laki-laki yang lebih banyak daripada perempuan, yaitu 
sebesar 53,2\%. Pada wanita penurunan GFR terjadi lebih lambat, hal ini dikarenakan pada perempuan tekanan darah sistolik $10 \mathrm{mmHg}$ lebih rendah daripada laki-laki. Tekanan darah merupakan salah satu faktor penentu utama terjadinya aterosklerosis dan perkembangan PGK. Hal lain yang dapat berpengaruh pada laju terjadinya penurunan fungsi ginjal antara lain perbedaan kondisi hormonal dan gaya hidup, seperti asupan protein, garam, merokok, alkohol dan konsumsi minuman suplemen (Halbesma dkk., 2008).

Hasil analisis statistik karakteristik pasien menunjukkan bahwa pada dua kelompok (pasien yang menggunakan epoetin alfa dan epoetin beta) terdapat perbedaan proporsi pada variabel jenis kelamin, kategori usia, frekuensi hemodialisis per minggu, lama menjalani hemodialisis, kategori kadar $\mathrm{Hb}$, dan komorbid. Hal ini ditunjukkan dengan nilai signifikansi $(p<0,05)$ pada masing-masing variabel tersebut.

Perbandingan Kualitas Hidup Pasien yang Menjalani Hemodialisis dengan Terapi Epoetin Alfa dan Epoetin Beta Item pertanyaan dalam KDQOL-

SF versi 1.3 dikelompokkan ke dalam 4 domain yaitu domain kesehatan fisik, domain penyakit ginjal, domain kesehatan mental, dan domain kepuasan pasien. Domain kesehatan fisik meliputi parameter fungsi fisik, status pekerjaan, peran secara fisik, persepsi kesehatan umum, nyeri, energi/ kelelahan, dan fungsi sosial. Domain penyakit ginjal meliputi fungsi kognitif, gejala/ problem, efek penyakit ginjal, fungsi seksual, dan tidur. Domain kesehatan mental meliputi kesejahteraan emosi, kualitas interaksi sosial, beban penyakit ginjal, dukungan sosial, dan peran emosional. Domain kepuasan pasien terdiri dari parameter kepuasan pasien, dan dorongan staf dialisis.

Perbandingan skor kualitas hidup pasien yang termasuk skala numerik dilakukan dengan independent $t$ test jika data terdistribusi normal, jika data tidak terdistribusi normal maka uji MannWhitney dapat digunakan sebagai alternatif (Dahlan, 2014). Skor kualitas hidup pasien yang menjalani hemodialisis menggunakan epoetin alfa dan epoetin beta dapat dilihat pada tabel III. Perbandingan skor kualitas hidup pasien antar kelompok masih perlu diuji dengan ANCOVA karena proporsi karakteristik pasien kelompok epoetin alfa dan epoetin beta pada beberapa variabel terdapat perbedaan.

Skor kualitas hidup berdasarkan domain dengan rata-rata terendah pada kelompok epoetin alfa adalah domain kesehatan fisik sebesar 55,26 $\pm 19,01$, namun pada kelompok epoetin beta nilai rata-rata terendah adalah pada domain penyakit ginjal sebesar $57,08 \pm 18,63$. Hasil analisis perbandingan skor kualitas hidup domain kesehatan fisik antara kelompok epoetin alfa dan epoetin beta dengan indepent $t$-test menunjukkan bahwa skor domain kesehatan fisik antar kelompok berbeda tidak bermakna, termasuk pada parameter fungsi fisik, status pekerjaan, peran secara fisik, persepsi kesehatan umum, nyeri, energi/ kelelahan, dan fungsi sosial. $\mathrm{Hal}$ ini ditunjukkan dengan nilai $\mathrm{p}>0,05$. Penelitian Wandilla (2014) pada 24 pasien hemodialisis di RS Akademik Yogyakarta juga didapatkan rata-rata skor kualitas hidup terendah pada domain kesehatan fisik sebesar 53,8 $\pm 10,1$. Penelitian Shrestha dkk. (2008) menyebutkan bahwa domain kualitas hidup pasien hemodialisis yang paling rendah terdapat pada domain kesehatan fisik. Kondisi PGK menyebabkan penurunan kesehatan fisik seperti penurunan kemampuan berjalan, menaiki tangga, membungkuk, mengangkat, gerak badan, dan kemampuan aktivitas berat. Penurunan kesehatan fisik ini menyebabkan keterbatasan sehingga mengganggu pekerjaan serta aktivitas sehari-hari, seperti memperpendek waktu untuk bekerja atau beraktivitas dan kesulitan dalam beraktivitas (Hays dkk., 1997). 
Tabel III. Rata-rata skor kualitas hidup pasien hemodialisis yang menggunakan epoetin alfa dan epoetin beta di RS PKU Muhammadiyah Yogyakarta

\begin{tabular}{|c|c|c|c|c|}
\hline \multirow[t]{2}{*}{ Domain } & \multirow[t]{2}{*}{ Parameter } & \multicolumn{2}{|c|}{ Mean \pm SD } & \multirow[t]{2}{*}{ p value } \\
\hline & & $\begin{array}{c}\text { Epoetin alfa } \\
(\mathrm{n}=71)\end{array}$ & $\begin{array}{l}\text { Epoetin beta } \\
(n=32)\end{array}$ & \\
\hline \multirow[t]{8}{*}{ Kesehatan fisik } & Fungsi Fisik & $51,48 \pm 25,49$ & $60,62 \pm 24,32$ & $0,096^{\mathrm{a}}$ \\
\hline & Status pekerjaan & $67,96 \pm 44,86$ & $79,68 \pm 39,88$ & $0,187^{\mathrm{b}}$ \\
\hline & Peran fisik & $26,17 \pm 29,69$ & $34,37 \pm 29,61$ & $0,179^{\mathrm{b}}$ \\
\hline & Persepsi kesehatan umum & $51,01 \pm 18,49$ & $55,37 \pm 22,88$ & $0,318^{\mathrm{a}}$ \\
\hline & Nyeri & $55,43 \pm 27,27$ & $58,09 \pm 24,43$ & $0,641^{\mathrm{a}}$ \\
\hline & Energi/ kelelahan & $72,42 \pm 17,70$ & $72,57 \pm 19,00$ & $0,968^{a}$ \\
\hline & Fungsi sosial & $62,38 \pm 29,30$ & $69,60 \pm 26,58$ & $0,229^{b}$ \\
\hline & Total & $55,26 \pm 19,01$ & $61,47 \pm 20,69$ & $0,146^{\mathrm{a}}$ \\
\hline \multirow[t]{6}{*}{ Penyakit ginjal } & Fungsi kognitif & $65,28 \pm 24,85$ & $64,27 \pm 29,95$ & $0,938^{\mathrm{b}}$ \\
\hline & Gejala/ problem & $57,38 \pm 17,07$ & $56,16 \pm 17,18$ & $0,742^{a^{*}}$ \\
\hline & Fungsi seksual & $25,39 \pm 38,31$ & $30,07 \pm 40,39$ & $0,542^{b}$ \\
\hline & Efek penyakit ginjal & $74,41 \pm 16,78$ & $75,52 \pm 16,84$ & $0,683^{b}$ \\
\hline & Tidur & $64,11 \pm 23,47$ & $59,49 \pm 25,00$ & $0,949^{\mathrm{a}}$ \\
\hline & Total & $57,32 \pm 14,97$ & $57,08 \pm 18,63$ & $0,945^{\mathrm{a}}$ \\
\hline \multirow[t]{6}{*}{ Kesehatan mental } & Kesejahteraan emosional & $82,56 \pm 17,90$ & $86,68 \pm 17,98$ & $0,184^{b}$ \\
\hline & Kualitas interaksi sosial & $79,19 \pm 20,64$ & $80,83 \pm 22,51$ & $0,584^{b}$ \\
\hline & Beban penyakit ginjal & $40,52 \pm 23,49$ & $40,19 \pm 24,90$ & $0,949^{\mathrm{a}}$ \\
\hline & Dukungan sosial & $86,58 \pm 18,16$ & $89,84 \pm 19,01$ & $0,264^{b}$ \\
\hline & Peran emosional & $34,37 \pm 37,07$ & $53,12 \pm 45,48$ & $0,047^{\mathrm{b}^{*}}$ \\
\hline & Total & $64,64 \pm 16,57$ & $70,13 \pm 18,32$ & $0,143^{\text {a }}$ \\
\hline \multirow[t]{3}{*}{ Kepuasan pasien } & Kepuasan pasien & $58,85 \pm 15,41$ & $61,97 \pm 19,50$ & $0,628^{\mathrm{b}}$ \\
\hline & Dorongan staf dialisis & $86,71 \pm 18,75$ & $92,26 \pm 16,40$ & $0,077 \mathrm{~b}$ \\
\hline & Total & $72,78 \pm 13,00$ & $77,12 \pm 14,02$ & $0,078^{b}$ \\
\hline \multicolumn{2}{|c|}{ Skor rata-rata kualitas hidup keseluruhan } & $60,25 \pm 12,97$ & $63,93 \pm 15,53$ & $0,224^{a}$ \\
\hline
\end{tabular}

Perbandingan rata-rata skor domain kesehatan mental pada parameter kesejahteraan emosi, kualitas interaksi sosial, beban penyakit ginjal, dan dukungan sosial antar kedua kelompok menunjukkan hasil yang berbeda tidak bermakna. Hasil analisis perbandingan rata-rata skor kualitas hidup domain kesehatan mental pada parameter peran emosional antara kelompok epoetin alfa dan kelompok epoetin beta menunjukkan hasil yang berbeda bermakna dengan nilai $\mathrm{p}<0,05$. Rata-rata skor kualitas hidup parameter peran emosional kelompok epoetin alfa lebih rendah $(34,37 \pm 37,07)$ dibandingkan dengan kelompok epoetin beta $(53,73 \pm 45,48)$, namun perbandingan rata-rata skor kualitas hidup domain kesehatan mental antara kedua kelompok menunjukkan hasil yang berbeda tidak bermakna $(p>0,05)$. Rata-rata skor kualitas hidup domain kesehatan mental pada kelompok epoetin alfa diperoleh sebesar 64,66 $\pm 16,65$, sedangkan pada kelompok epoetin beta sebesar

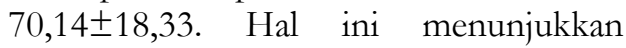
bahwa perbedaan yang bermakna pada parameter peran emosional antara kedua kelompok tidak memberikan pengaruh yang besar pada domain kesehatan mental. Rata-rata skor kualitas hidup pasien pada domain kesehatan mental lebih tinggi dibandingkan dengan domain kesehatan fisik. Hal ini sejalan dengan penelitian Seica dkk. (2009) yang menyebutkan bahwa meskipun status kesehatan fisik memburuk, namun kesehatan mental pasien hemodialisis relatif terpelihara dengan baik. Hal ini dikarenakan kemampuan beradaptasi dan harapan pasien terkait penyakit kronis yang mereka derita.

Rata-rata skor domain penyakit ginjal pada kelompok epoetin alfa sebesar $58,10 \pm 16,07$, sedangkan pada kelompok epoetin beta sebesar 57,08 $\pm 18,63$. Hasil 
analisis perbandingan rata-rata skor domain penyakit ginjal antar kedua kelompok menunjukkan bahwa rata-rata skor kedua kelompok berbeda tidak bermakna. Rata-rata skor kedua kelompok pada domain penyakit ginjal termasuk rendah. Hal ini berbeda dengan penelitian Wandilla (2014) dan ALJumaih dkk. (2011) yang memperoleh hasil bahwa skor tertinggi kualitas hidup pasien hemodialisis pada domain penyakit ginjal.
Rata-rata skor kualitas hidup domain kepuasan pasien pada kelompok epoetin alfa sebesar 72,29 $\pm 12,87$, sedangkan pada kelompok epoetin beta

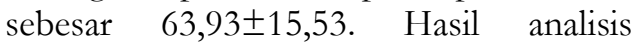
perbandingan rata-rata skor kualitas hidup domain kepuasan pasien pada kelompok epoetin alfa dan epoetin beta menunjukkan perbedaan yang bermakna $(\mathrm{p}<0,05)$.

Tabel IV. Hasil uji ANCOVA

\begin{tabular}{ll}
\hline \multicolumn{1}{c}{ Variabel } & $p$-value \\
\hline Corrected model & 0,006 \\
\hline Intercept & 0,001 \\
\hline Kategori usia & 0,179 \\
\hline Jenis kelamin & 0,584 \\
\hline Frekuensi hemodialisis per minggu & 0,114 \\
\hline Durasi hemodialisis & 0,009 \\
\hline Kategori Hb & 0,689 \\
\hline Komorbid & 0,025 \\
\hline Kelompok EPO & $0,424^{*}$ \\
\hline
\end{tabular}

Keterangan: *berbeda tidak bermakna

Rata-rata skor kualitas hidup keseluruhan pasien yang menggunakan epoetin alfa sebesar $60,25 \pm 12,97$, sedangkan skor rata-rata kualitas hidup keseluruhan pasien yang menggunakan epoetin beta sebesar 63,93 $\pm 15,53$, dengan nilai signifikansi $0,269(>0,05)$. Hal ini menunjukkan bahwa skor kualitas hidup keseluruhan pasien yang menggunakan epoetin alfa berbeda tidak bermakna dengan skor kualitas hidup keseluruhan pasien yang menggunakan epoetin beta. Skor kualitas hidup keseluruhan pada kedua kelompok dalam penelitian ini termasuk baik, karena berdasarkan KDQOL-SF vers 1.3 A Mannual for Use and Scoring, skor kualitas hidup pasien hemodialisis dikatakan baik jika skor kualitas hidupnya $>59$.

Perbandingan Kualitas Hidup Pasien yang Menjalani Hemodialisis dengan Terapi Epoetin Alfa dan Epoetin Beta setelah dikontrol dengan beberapa variabel

Berdasarkan hasil analisis homogenitas variabel penelitian bahwa terdapat beberapa variabel yang tidak homogen, meliputi variabel kategori usia, jenis kelamin, frekuensi hemodialisis, durasi hemodialisis, kategori $\mathrm{Hb}$, dan komorbid, sehingga dilakukan analisis multivariat dengan ANCOVA. Hasil uji ANCOVA dapat dilihat pada tabel IV.

Berdasarkan pengujian

ANCOVA, variabel durasi hemodialisis dan komorbid diketahui dapat berkontribusi terhadap kualitas hidup pasien. Perbandingan skor kualitas hidup pasien antara kelompok epoetin alfa dan epoetin beta secara keseluruhan setelah dikontrol dengan variabel durasi hemodialisis dan komorbid menunjukkan hasil yang berbeda tidak bermakna $(\mathrm{p}>0,05)$. Hal ini menunjukkan bahwa penggunaan epoetin alfa dan epoetin beta tidak memberikan perbedaan yang bermakna dari segi kualitas hidup pasien secara keseluruhan.

\section{Simpulan}

Kualitas hidup pasien keseluruhan yang menjalani hemodialisis dengan terapi epoetin alfa dan epoetin beta di RS PKU Muhammadiyah Yogyakarta menunjukkan hasil yang 
berbeda tidak bermakna yaitu sebesar $60,25 \pm 12,97$ pada kelompok epoetin alfa dan $63,93 \pm 15,53$ pada kelompok epoetin beta.

\section{Ucapan Terimakasih}

Terimakasih kepada DIKTI yang telah memberikan dana untuk terselesainya penelitian ini dan RS PKU Muhammadiyah Yogyakarta sebagai tempat pelaksanaan penelitian

\section{Daftar Pustaka}

Dahlan, M. S., 2014. Statistik untuke Kedokteran dan Kesehatan. Epidemiologi Indonesia.

Eschbach, J. W., 2000. Anemia in Chronic Renal Failure. Dalam R. J. Johnson dan J. Feehally (Eds.), Compr. Clin. Nephrol. London; New York: Mosby.

Hays, R. D., Kallich, J. D., Mapes, D. L., Coons, S. J., Amin, N., Carter, W. B., dkk., 1997. Kidney Disease Quality of Life Short Form (KDQOL-SFTM), Version 1.3: A Manual for Use and Scoring. RAND.

Loos, C., Briançon, S., Frimat, L., Hanesse, B., dan Kessler, M., 2003. Effect of end-stage renal disease on the quality of life of older patients. J. Am. Geriatr. Soc., 51(2), 229-233.
PERNEFRI., 2011. Konsensus Manajemen Anemia pada Pasien gagal Ginjal Kronik. Jakarta: PERNEFRI.

Seica, A., Segall, L., Verzan, C., Văduva, N., Madincea, M., Rusoiu, S., dkk., 2009. Factors affecting the quality of life of haemodialysis patients from Romania: a multicentric study. Nephrol. Dial. Transplant. Off. Publ. Eur. Dial. Transpl. Assoc. - Eur. Ren. Assoc., 24(2), 626-629.

Shrestha, S., Ghotekar, L., Sharma, S., Shangwa, P., dan Karki, P., 2008. Assessment of quality of life in patients of end stage renal disease on different modalities of treatment. JNMA J Nepal Med Assoc, 47 (169), 1-6.

Smeltzer, S., 2005. Buku Ajar Keperawatan Medikal Bedah Brunner \& Suddarth. Jakarta: EGC.

Valderrabano, F., Horl, W. H., Jacobs, C., Macdougall, I. C., Parrondo, I., Cremers, S., dkk., 2000. European best practice guidelines 1-4: evaluating anaemia and initiating treatment. Nephrology Dialysis Transplantation, 15, 8-14.

Wandilla, I., 2014. Hubungan Kadar Hormon Paratiroid Intak dengan Kualitas Hidup Pasien Hemodialisis yang Diberikan Kalsium Karbonat. Universitas Gadjah Mada, Yogyakarta. 